\title{
Potential Anti-Cancer, Cytotoxic and Antioxidant of Polar and Non-Polar Extracts of Origanummajorana Linn
}

\author{
Eliana Marcela Soto Rueda 1,2, Rodrigo Andrés Restrepo ', Nelsy Loango, , , Beatriz Restrepo', \\ Patricia Landázuri ${ }^{1 *}$ and Mahendra Rai ${ }^{3}$ \\ 'Facultad de Ciencias de la Salud- Universidad del Quindío, Quindío, Colombia; eli.soto.2@hotmail.com, \\ rodrigo_osorio502@hotmail.com,neloango@uniquindio.edu.co, beatrizrc@uniquindio.edu.co, \\ plandazu@uniquindio.edu.co \\ 2Programa de Biología- Facultad de Ciencias Básicas- Universidad del Quindío, Quindío, Colombia \\ ${ }^{3}$ Department of Biotechnology, SGB Amravati University, Amravati - 444602, Maharashtra, India; \\ mahendrarai7@gmail.com
}

\begin{abstract}
Objective: To evaluate the anticancer and cytotoxic activity of the Origanum majorana and also to test its antioxidant potential. Methods/Statistical Analysis: The in vitro anticancer and cytotoxic activity of the Polar (PF) and Non-Polar Fraction (NPF) obtained from a total Ethanolic Extract (EE) of O. majorana were evaluated using the murine myeloma cell lines Sp2/O-Ag14 (ATCC: CRL-1581) and VERO-ATCC-CCL81. The cell viability was measured with the Colorimetric Quantification System of the Transmittance Index (CQSTI) method; a simple ANOVA of the CQSTI values of each cell line treated with the different extracts was carried out. Findings: The preliminary phytochemical analysis determined the presence of tannins, flavonoids and terpenes in the fractions. EE and PF showed a strong DPPH free radical scavenging capacity, 88,8 and 85.9\% uptake, respectively. EE and PF displayed promising anti anticancer activity for both cell lines, so, EE, PF and NPF concentrations that produced $50 \%$ cell viability included $5.7 \mathrm{mg} / \mathrm{mL}, 5.8 \mathrm{mg} / \mathrm{mL}$ and $35.8 \mathrm{mg} / \mathrm{mL}$, respectively. Application/Improvements: For the first time it is shown that the PF from O. majoranaa low concentrations affected myeloma cells but not VERO cells. These results indicate that this fraction has an anticancer activity. In addition, our results demonstrated that the PF has a high phenolic content, this could be related to its cytotoxic activity.
\end{abstract}

Keywords: Anticancer, Antioxidant, Cytotoxic, Extract, Flavonoids, O. marjorana, Phenolic Compounds

\section{Introduction}

Plants have been used in traditional medicine as therapeutic alternatives for the prevention and treatment of various diseases, including cardiovascular diseases and inflammatory disorders, and may even reduce cancer risk $^{1,2}$.

It has been shown that certain plants have a high antioxidant capacity. Natural antioxidants are studied extensively because of their ability to eliminate free radicals, which are known to damage cellular biomolecules
(DNA, proteins, lipids, amines and carbohydrates) and whose accumulation causes oxidative stress, which is highly related to degenerative diseases such as cancer, cardiovascular malfunction, diabetes, Alzheimer's and Parkinson's disease, in addition to contributing to the aging process $-\underline{3-6}$.

Because of the global threat of cancer, biomedical scientists are continuously searching for new natural compounds that can be used in the treatment of this disease or as potential adjuvants, with greater efficiency and fewer side effects ${ }^{7}$.

${ }^{*}$ Author for correspondence 
O. majorana L, of the family Lamiaceae, commonly known as marjorana, has been used in traditional medicine for the treatment of different diseases $\stackrel{8}{;}$; various extracts of O. majorana have shown a high antioxidant potential? 10 . Studies on the anticancer activity of $O$. majorana have confirmed that this property inhibits the proliferation of leukemic and breast cancer cells $s^{11,12}$; another study demonstrated ant proliferative effect through the suppressing activity of the NF-kB gene expression and the high antioxidant activity in the hepatocarsinoma cell line of $O$. majoran $a^{\frac{13}{3}}$. The anticancer activity of $O$. majorana has only been studied in raw or total extracts aqueous (solution of the soluble principles of a plant), ethanolic (base in ethanol extraction) or hydroalcoholic extracts base in water and ethanol or methanol) and essential oils; but as far as it is known, the polar and non-polar fractions of the total ethanolic extract have not been studied. The objective of this study was to determine anticancer and cytotoxic activity of the polar and non-polar fractions of aethanolicextract of $O$. majorana, and also to verify the antioxidant capacity with the aim of contributing to the search for active ingredients related to their cytotoxic activity.

\section{Materials and Methods}

\subsection{Collection and Drying of the Plant Material}

O. majorana was acquired from a local market in the city of Armenia. A voucher plant specimen was deposited in Herbarium of the Universidad del Quindío for taxonomic identification (HUQ034140).

\subsection{Ethanolic Extract of O. majorana L.}

\section{Preparation}

The leaves of O. majorana were dried in an oven at $38^{\circ} \mathrm{C}$, until constant weight was obtained, then homogenized; this material was subjected to leaching with $95 \%$ ethanol for 15 days. The resulting extract was concentrated with rotary evaporation at low pressure and vacuum filtered. The chlorophylls of the extract were precipitated and separated with an ethanol water mixture (1:7), and then stored at $-20^{\circ} \mathrm{C}$ until use. Throughout the cell culture experiments, stock solutions were diluted with RPMI 1640 medium and DMEM (Dulbeco ${ }^{\circ}$ ).

\subsection{Polar and Non-Polar Fractions}

\section{Preparation}

For raw extract fractionation, $10.5 \mathrm{~g}$ of the extract was taken and mixed with silica gel at (beads $0.063-0.2 \mathrm{~mm}$ ) a ratio of $1: 2$, as described by ${ }^{14}$. The fractionation was carried out with a glass column for chromatography. Nonpolar fraction separation was started with chloroform as eluent. The fractionation of the non-polar compounds was stopped when no any secondary metabolite was present in the thin-layer chromatography assays. Once the NPF was obtained, the fractionation was continued gradually with absolute ethanol until the Polar Fraction $(\mathrm{PF})$ was obtained. An ethanol-water mixture was used to extract the polar retentate of the extract, which was added to the PF.

\subsection{Preliminary Phytochemical Analysis}

The raw extract and its polar and non-polar fractions were evaluated for the identification of tannins, saponins, flavonoids, quinones, sterols, triterpenoids, naphthoquinones and anthraquinones, cardiotonic glycosides, terpenic lactones and alkaloids following the method described by ${ }^{14,15}$.

\subsection{DPPH Radical Scavenging Activity}

Concentrations of $2.5,8,14,20,26$, and $32 \mu \mathrm{g} / \mathrm{mL}$ were evaluated for theEE and PF, and concentrations of 0.8 , 1.6, 2.4, 3.2, and $4.5 \mathrm{mg} / \mathrm{mL}$ were evaluated for the PAF, prepared in methanol. $1 \mathrm{~mL}$ of methanol solution of the extract or fraction was taken, then, $0.5 \mathrm{~mL}$ of a DPPH solution (1,1-diphenyl-2-pricrilhidrazil free radical) $(0.2 \mathrm{mM}$ in methanol) was added and mixed. The mixture was incubated at $25^{\circ} \mathrm{C}$ for 40 minutes in the dark, and the absorbance was read at $517 \mathrm{~nm}$. Methanol was used as the blank. As a positive control, Butylated Hydroxy Toluene (BHT) in methanol was used at the same concentrations of the extract. The negative control was $0.5 \mathrm{~mL}$ of $\mathrm{DPPH}^{\circ}$ solution plus $1 \mathrm{~mL}$ of methanol ${ }^{16}$.

The $\mathrm{DPPH}^{\circ}$ radical savaging percentage was calculated according to the following formula:

DPPH radicals uptake $\%=(\mathrm{Ac}-\mathrm{A} / \mathrm{Ac})_{{ }_{*} 00}(1)$

Where:

Ac: Absorbance of the negative control 
A: Absorbance of the sample (with extract or with BHT).

\subsection{Total Phenolic Content}

The total phenolic content of $1 \mathrm{mg} / \mathrm{mL}$ of each of the extracts,EE, PF, and NPF, was evaluated with tungsten and molybdenum salts by adding the Folin-Ciocalteau reagent and $\mathrm{Na}_{2} \mathrm{CO}_{3}$; brebely: $2.5 \mathrm{~mL}$ of the Folin-Ciocalteau reagent $\left(1 / 10\right.$ dilution) and $2 \mathrm{~mL}$ of $7.5 \% \mathrm{Na}_{2} \mathrm{CO}_{3}(\mathrm{w} / \mathrm{v})$ were added to the extract, which was incubated at $40^{\circ} \mathrm{C}$ for 15 minutes. The absorbance of the samples was measured at $765 \mathrm{~nm}$; as a blank, $7.5 \% \mathrm{Na}_{2} \mathrm{CO}_{3}$ was used in distilled water. The results were expressed as mg Eq- of gallic acid/g of extract $\frac{16}{}$.

\subsection{Anticancer Activity and Cytotoxicity}

For the determination of the anticarcinogenic activity, Sp2/O-Ag14 (ATCC: CRL-1581) murine myeloma cells were used; approximately, 10,000 cells per well were placed in a 96-well plate with RPMI 1640 medium $\left(\right.$ Dulbeco $\left.^{\circ}\right)$, supplemented with fetal bovine serum (Invitrogen), antibiotics (Penicillin-Streptomycin) - antifungal (Amphotericin B), and L-Glutamine; the cells were incubated at a temperature of $37^{\circ} \mathrm{C}$ and an atmosphere with $5 \% \mathrm{CO}_{2}$.

For the cytotoxicity determination, Vero cells isolated from African adult green monkey kidney epithelium, Cercopithecusaethiops, were used. Approximately, 10,000 cells per well were placed in a 96-well plate with DMEM medium (Dulbeco ${ }^{\circ}$ ), supplemented with fetal bovine serum (Invitrogen), antibiotics (Penicillin-Streptomycin) - antifungal (Amphotericin B), and L-Glutamine; the cells were incubated at a temperature of $37^{\circ} \mathrm{C}$ and an atmosphere with $5 \% \mathrm{CO}_{2}$.

\subsection{Evaluation of Cell Viability}

Cell viability was determined byalamar Blue ${ }^{\star}$ assay and a color quantification system was based on images (CQSColorimetric Quantification System); so, cell viability was estimated by determining alamar Blue reduction whit digital images processing (CQSTI transmittance index). Digital cameras, with red, green and blue (RGB) filters, captured red (600 to $700 \mathrm{\eta m}$ ) and green (from 500 to 600 $\eta \mathrm{m}$ ) light wavelengths in ranges bordering the absorption bands of resazurin and resorufin ${ }^{17}$.

In order to measure the well signals, color images of an empty microplate (blank) and of a microplate loaded with samples were captured and analyzed using the software Image $\mathrm{J}^{17}$. The CQSTI transmittance index was calculated with the following formula:

$\mathrm{CQSTI}_{\mathrm{mn}}=\mathrm{Wr}_{\mathrm{mn}} \mathrm{x}\left(\mathrm{MAXBr} / \mathrm{Br}_{\mathrm{mn}}\right)-\mathrm{Wg}_{\mathrm{mn}} \mathrm{x}(\mathrm{MAXBg}$

$\left./ \mathrm{Bg}_{\mathrm{mn}}\right)(2)$

Where:

$\mathrm{m}=$ Microplate column

$\mathrm{n}=$ Microplate row

$\mathrm{Wr}_{\mathrm{mn}}=$ red spectrum density of the well

$\mathrm{Wg}_{\mathrm{mn}}=$ green spectrum density of the well

$\mathrm{Br}_{\mathrm{mn}}=$ red spectrum density of the well of the empty microplate image (blank)

$\mathrm{Bg}_{\mathrm{mn}}=$ green spectrum densityof the well of the empty microplate image (blank)

$\mathrm{MAXBr}=$ The highest value of $\mathrm{Br}$ of the empty microplate image (blank)

MAXBgr $=$ The highest Bg value of the empty microplate image (blank)

CQSTI values of each extract indirectly interpreted as cell viability or ant carcinogenic effect in the murine myeloma cells.

\subsection{Statistical Analysis}

A simple ANOVA of the CQSTI values of each cell line treated with the different extracts was performed and a multi-rank test was performed to determine which means were significantly different from others. The statistical program Statgraphics Centurion XV was used.

\section{Results and Discussion}

\subsection{Preliminary Phytochemical Analysis of the EE, PF and NPF of O. majorana}

The evaluation of the presence of the secondary metabolites in the different extracts was carried out qualitatively with chemical reactions that alter the molecular structure of compounds. This analysis indicated the presence of tannins, anthocyanins, flavonoids, terpenes, quinones, alkaloids (from the purines group), cardiotonics, coumarins and terpenic lactones, some of which were revealed with thin-layer chromatography using UV light.

The vibrational analysis of the infrared spectrum indicated the presence of $\mathrm{C}-\mathrm{H}$ bonds in several of the peaks seen in the NPF spectrogram, demonstrating the possible presence of compounds such as terpenes or triterpenes in this fraction. The infrared spectrogram for the 
PF showed vibration bands of $\mathrm{OH}$ bonds at $3420.66 \mathrm{~cm}-1$, $\mathrm{CH}$ at $2924.66 \mathrm{~cm}-1, \mathrm{C}=\mathrm{C}$ at $1074.13 \mathrm{~cm}-1-1628.15$ $\mathrm{cm}-1$, these types of vibrations possibly they are indicative of phenolic or polyphenolic compounds ${ }^{18}$.

\subsection{DPPH Radical Scavenging Activity}

In this study, the CE and PF showed a strong DPPH free radical scavenging capacity, where the maximum uptake of DPPH radicals was found in the EE and PF, 88, 85 and 85.9\% uptake, respectively.

The EE and its polar fraction PF had the highest DPPH radical scavenging activity; the IC50 was determined for the EE, PF and NPF (Table 1). The EE exhibited the highest percentage of radical uptake $(12.1 \mu \mathrm{g} / \mathrm{mL})$, and the NPF had a low capacity for inhibiting DPPH radicals $(2400 \mu \mathrm{g} / \mathrm{mL})$.

\subsection{Determination of the Total Phenolic Content}

The EE exhibited the highest content of phenolic compounds (458.4 mg Eq- of gallic acid/g of EE), followed by the PF (251.4 mg Eq- of gallic acid/g of PF). The nonpolar fraction had the lowest phenolic content $(9.6 \mathrm{mg}$ Eq- gallic acid/g NPF).

O. majorana L. has a marked antioxidant potential because a very good free radical scavenging percentage was obtained at low concentrations; in addition, the measured phenolic content showed that the raw extract and the polar fraction possessed a considerable amount of phenols. The high content of phenolic compounds in O. majorana has been related to its ability to eliminate free radicals associated with its strong antioxidant activity $^{12}$. Several reports have indicated that $O$. majorana has a high capacity for inhibiting DPPH radicals ${ }^{11}, 19$. When comparing the obtained values, it was concluded that the polar compounds present in the O. majorana in this study exhibited a higher radical scavenging percentage and phenolic content, with higher results than in the

Table 1. Determination of the concentration that inhibited 50\% (IC50) of the DPPH radicals of the raw extract and polar and non-polar fractions of $O$. majorana

\begin{tabular}{llll}
\hline IC50/ & $\begin{array}{l}\text { Ethanolic } \\
\text { Extract } \\
(\mu \mathrm{g} / \mathrm{mL})\end{array}$ & $\begin{array}{l}\text { Polar Fraction } \\
(\mu \mathrm{g} / \mathrm{mL})\end{array}$ & $\begin{array}{l}\text { Non-polar Fraction } \\
(\mu \mathrm{g} / \mathrm{mL})\end{array}$ \\
\hline IC50 & $12.1 \pm 1.3$ & $16.7 \pm 2.0$ & $2400 \pm 0.17$ \\
\hline
\end{tabular}

described studies ${ }^{11}$. This may have been due to the fact that its active components were altered by differences in the geographical richness from which the plants were obtained and by climatic characteristics such as temperature and humidity ${ }^{20}$.

\subsection{Anticancer and Cytotoxic Activity of the EE, PF and NPF of O. majorana.}

The CQSTI values of the different concentrations of the NPF, PF, EE and control exhibited a statistically significant difference $(\mathrm{P}<0.05)$.So, $\mathrm{PF}$ concentrations from 6.4 to $10, \mathrm{mg} / \mathrm{mL}$ and NPF concentration from 36 to $45 \mathrm{mg} / \mathrm{mL}$ affected myeloma cells but not VERO cells. PF had a better performance at low concentrations than NPF. This results indicates that these fractions have a cytotoxic potential in murine myeloma cells (anticancer activity) (Table 2).

A comparison analysis of multiple ranges was used to determine that 2 and $4 \mathrm{mg} / \mathrm{mL}$ of EE, 4 , an d 5.2, and 6.4 $\mathrm{mg} / \mathrm{mL}$ of PF and, 9,18 , and $27, \mathrm{mg} / \mathrm{mL}$ of NPF did not have statistically significant differences between them or when compared to control, which indirectly indicated the presence of viable cells in these wells and, therefore, low cytotoxicity.

The CQSTI-mediumwas obtained for these cell lines, interpreted as the concentration at which only half of the $\mathrm{AB}$ reduction occurs. The mean CQSTI of the EE, $\mathrm{PF}$ and NPF was obtained at the following concentrations: 5.7 $\mathrm{mg} / \mathrm{mL}, 5.8 \mathrm{mg} / \mathrm{mL}$ and $35.8 \mathrm{mg} / \mathrm{mL}$, respectively. These CQSTI- mean values indirectly indicate $50 \%$ cell viability.

The comparison of these values obtained in the determination of viability leads to the conclusion that the murine myeloma cell line Sp2/O-Ag14 is significantly sensitive to extracts of $O$. majoranaas it is shown in Figure 1. Studies have shown that low concentrations of O. majorana induce an accumulation of arrested cells in apoptosis-resistant mitosis and, at higher concentrations of O. majorana, trigger massive apoptosis in the breast cancer cells MDA-MB-231 $\frac{12}{2}$. O. majorana at low cytotoxicity concentrations has a high ant proliferative potential and strong pro-apoptotic effect on human lymphoblastic leukemia cells ${ }^{11}, \underline{21}$. The essential oil of $O$. majorana has been shown to have a cytotoxic and apoptotic effect on human hepatic carcinoma cells $s^{22}$. According to these authors and the results obtained in this study $O$. majorana has a promising ant carcinogenic effect, which should be considered for future research aimed at the determination and isolation of the active principles. 
Table 2. Cell viability of polar and non-polar fraction from O. majorana leaves

\begin{tabular}{llllll}
\hline PF Concentration & $\begin{array}{l}\text { CQSTI } \\
\text { (\%Viability) }\end{array}$ & $\begin{array}{l}\text { CQSTI } \\
\text { (\%Viability) }\end{array}$ & NPF Concentration & CQSTI (\%Viability) & $\begin{array}{l}\text { CQSTI } \\
\text { (\%Viability) }\end{array}$ \\
\hline $\mathrm{mg} / \mathrm{mL}$ & VERO & Myeloma & $\mathrm{mg} / \mathrm{mL}$ & VERO & Myeloma \\
4 & 47.02 & 100 & 9 & 48.14 & 100 \\
5.2 & 53.25 & 81.32 & 18 & 47.23 & 100 \\
6.4 & 58.32 & 9.6 & 27 & 53.44 & 100 \\
7.6 & 68.35 & 0 & 36 & 58.32 & 20.79 \\
8.8 & 77.27 & 0 & 45 & 51.15 & 0 \\
10 & 80.42 & 0 & 54 & 69.78 & 0 \\
\hline
\end{tabular}

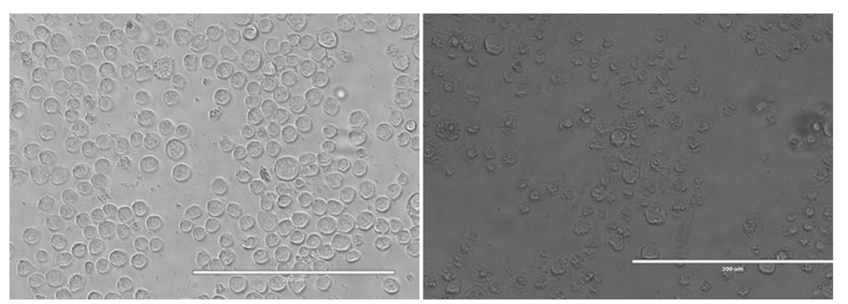

Figure 1. Effect of $O$. majorana $\mathrm{EE}$ on the murine myeloma cells Sp2/O-Ag14. A: $4 \mathrm{mg} / \mathrm{mL}$ and B: $11 \mathrm{mg} / \mathrm{mL}$.

O. majorana has low cytotoxicity in healthy lymphocytes $\frac{11}{}$, and its alcoholic, aqueous extracts and volatile oils have a protective effect on the toxicity of lead acetate in mice ${ }^{23}$. According to these reports, O. majorana has low cytotoxicity in healthy cells, and, according to this study, the tested concentrations of the fractions probably have low cytotoxicity, but they have a greater effect on murine myeloma cells and other cell line ${ }^{11,12,24}$.

This study has some limitations, for example, it did not delve into the type of compounds that the polar fraction has, and its possible ant carcinogenic effect.

\section{Conclusion}

The results obtained in this study and those found in literature show that $O$. majorana has a promising anticancer effect, with promising chemo preventive use, and should be considered for future research aimed at determining and isolating the active principles.

For the first time it is shown that the PF from O. majoranaa low concentrations affected myeloma cells but not VERO cells. This result indicates that this fraction has an anticancer activity. In addition, our results demonstrated that the PF has a high phenolic content; this could be related to its cytotoxic activity.
Plants have proven to be an excellent source of new drugs, including ant carcinogenic agents. The identification and development of new plant chemotherapeutic agents have gained significant recognition in the field of cancer therapy and have become an important area of experimental cancer research.

\section{Acknowledgments}

The authors thank research group GYMOL of the Universidad Del Quindío for donating the cell lines used in this study.

\section{References}

1. Alok SA, Kumar S, Verma A, Kumar M, Mahor A, Sabharwal M. Herbal antioxidant in clinical practice: A review. Asian Pacific Journal of Tropical Biomedicine. 2014; 4(1):78-84. https://doi.org/10.1016/S2221-1691(14)60213-6

2. Singh A, Singh S, Mohan PS. Role of medicinal plants for health perspective: Special reference to antioxidant potential. The Journal of Chemical Biology and Therapeutics. 2016; 1(2):1-5. https://doi.org/10.4172/2572-0406.1000106

3. Karadeniz A, Çinbilgel I, Gün SŞ, Çetin A. Antioxidant activity of some Turkish medicinal plants. Natural Product Research. 2015; 29(24):2308-12. https://doi.org/10.1080/14 786419.2015.1005618 PMid:25649168

4. Tungmunnithum D, Thongboonyou A, Pholboon A, Yangsabai A. Flavonoids and other phenolic compounds from medicinal plants for pharmaceutical and medical aspects: An overview. Medicines (Basel). 2018; 5(3):1-16. https://doi.org/10.3390/medicines5030093

5. Hamdy $\mathrm{MH}$, Mohamed Khaled AS, Abdel-Hamed S, Khalela I. Evaluation of antioxidant activity, total phenols and phenolic compounds in thyme (Thymus vulgaris L.), sage (Salvia officinalis L.), and marjoram (O.majorana L.) 
extracts. Industrial Crops and Products. 2013; 43:827-31. https://doi.org/10.1016/j.indcrop.2012.08.029

6. Karker M, Falleh H, Msaada K, Smaoui A, Abdelly C, Legault J, Ksouri R. Antioxidant, anti-inflammatory and anticancer activities of the medicinal halophyte Reaumuriavermiculata. Experimental and Clinical Sciences Journal. 2016; 15:297-307.

7. Wamidh HT, Adel MM. Antiproliferative activity of plant extracts used against cancer in traditional medicine. Scientia Pharmaceutica. 2010; 78(1):33-45. https://doi. org/10.3797/scipharm.0912-11 PMCid:PMC3002826

8. Hajlaoui $H$, Mighri $H$, Aouni M, Gharsallah N, Kadri A. Chemical composition and in vitro evaluation of antioxidant, antimicrobial, cytotoxicity and anti-acetylcholinesterase properties of Tunisian O. majorana L. essential oil. Microbial Pathogenesis. 2016; 95:86-94. https://doi.org/10.1016/j.micpath.2016.03.003

9. Zlotek U. Effect of jasmonic acid and yeast extract elicitation on low-molecular antioxidants and antioxidant activity of marjoram (O. majorana L). Acta Scientiarum Polonorum Technologia Alimentaria. 2017; 16(4):371-7. https://doi.org/10.17306/J.AFS.0505

10. Olfa B, Mariem A, Salah AM, Mouhiba BA. Chemical content, antibacterial and antioxidant properties of essential oil extract from Tunisian O. majorana L. cultivated under saline condition. Pakistan Journal of Pharmaceutical Sciences. 2016; 29(6):1951-8.

11. Abdel-Massih RM, Fares R, Bazzi S, El-Chami N, Baydoun E. The apoptotic and anti-proliferative activity of $O$. majorana extracts on human leukemic cell line. Leukemia Research. 2010; 34(8):1052-6. https://doi.org/10.1016/j.leukres.2009.09.018

12. Al Dhaheri Y, Eid A, Abu Qamar S, Attoub S, Khasawneh M. mitotic arrest and Apoptosis in Breast Cancer Cells induced by O.majorana extract: Upregulation of TNF-a and downregulation of survivin and mutant p53. Tizi-Ouzou, Algeria. PLoS ONE. 2013; 8(2):114. https://doi.org/10.1371/journal.pone.0056649 PMCid:PMC3579842

13. Fathy SA, Emam MA, Abo Agwa SH, Abu Zahra FA, Youssef FS, Sami RM. The antiproliferative effect of Origanummajorana on human hepatocarcinoma cell line: Suppression of NF-kB. Cellular and Molecular Biology. 2016; 62(10):80-4.

14. Bilbao MR. Análisis fitoquímico preliminar: química de los productos naturales. Universidad del Quindío. Armenia; 1997. p. $1-183$
15. Sanabria GA. Análisis fotoquímico preliminar: metodología y su aplicación en la evaluación de cuarenta plantas de la familia Compositae. Universidad Nacional de Colombia; 1983.

16. Gunjan G, Raj kumar V, Ashok KR, Lazar M. Therapeutic potential of polar and non-polar extracts of Cyanthillium cinereum In Vitro. Evidence Based Complementary and Alternative Medicine; 2009. p. 1-10.

17. Carneiro BR, Andrade LM, Gagioti SM, Barros $\mathrm{F}$ de $\mathrm{M}$, Andrade PM. A simple method to measure cell viability in proliferation and cytotoxicity assays. Brazilian Oral Research. 2009; 23(3):255-62. https://doi.org/10.1590/S1806-83242009000300006

18. Schulz H, Baranska M, Baranski R. Potential of NIR-FT-Raman spectroscopy in natural carotenoid analysis. Biopolymers. 2005; 77(4):212-21. https://doi.org/10.1002/bip.20215 19. Hossain MB, Brunton NP, Patras A, Tiwari B, O’Donnell CP, Martin-Diana $A B$, Barry-Ryan C. Optimization of ultrasound assisted extraction of antioxidant compounds from marjoram (Origanummajorana L.) using response surface methodology. Ultrasonics Sono Chemistry. 2012; 9(3):582-90. https://doi.org/10.1016/j.ultsonch.2011.11.001

20. Vági E, Rapavi E, Hadolin $M$, Vásárhelyiné Perédi K, Balázs A, Blázovics A, Simándi B. Phenolic and triterpenoid antioxidants from Origanummajorana L. herb and extracts obtained with different solvents. Journal of Agricultural and Food Chemistry. 2005; 53(1):17-21. https://doi.org/10.1021/jf048777p

21. Hazem SE, Armentano MF, Carmosino M, Bufo SA, De Feo V, Camele I. Cytotoxic activity of Origanumvulgare L. on hepatocellular carcinoma cell line HepG2 and evaluation of its biological activity. Molecules. 2017; 22(9).

22. Erdogana A, Ozkana A. Investigatıon of antioxıdative, cytotoxic, membrane-damaging and membrane-protective effects of the essential oil of Origanummajorana and its oxygenated monoterpene component linalool in humanderived Hep G2 cell line. Iranian Journal of Pharmaceutical Research. 2017; 16:24-34.

23. El-Ashmawy IM, el-Nahas AF, Salama OM. Protective effect of volatile oil, alcoholic and aqueous extracts of Origanummajoranaonleadacetatetoxicityin mice.Basicand Clinical Pharmacology and Toxicology. 2005; 97(4):238-43. https://doi.org/10.1111/j.1742-7843.2005.pto_136.x

24. Khaleel FM, Hameed SH, Taghreed M. In vitro cytotoxic effect of aqueous extract of $\mathrm{O}$. on AMN-3 cell line. Journal of Natural Sciences Research. 2016; 6(16):1-4. 